\title{
In situ Corrosion Study of Copper and Copper-Alloys Exposed to Natural Seawater of the Veracruz Port (Gulf of Mexico)
}

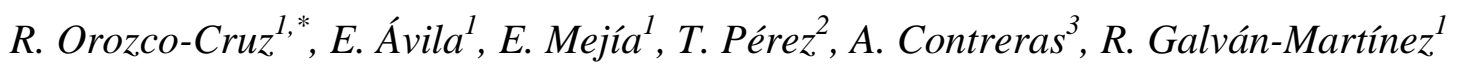 \\ ${ }^{1}$ Unidad Anticorrosión-Instituto de Ingeniería, Universidad Veracruzana, Av. S. S. Juan Pablo II, Zona \\ Universitaria, Boca del Río, Veracruz, 94294, México \\ ${ }^{2}$ Centro de Investigación en Corrosión (CICORR). Universidad Autónoma de Campeche, Av. Agustín \\ Melgar S/N, Campeche, Campeche, 24039, México. \\ ${ }^{3}$ Instituto Mexicano del Petróleo, Eje Central Lázaro Cárdenas Norte 152, San Bartolo Atepehuacán, \\ 07730, México. \\ *E-mail: rorozco@uv.mx
}

doi: $10.20964 / 2017.04 .27$

Received: 19 October 2016 / Accepted: 18 January 2017 / Published: 12 March 2017

In this study, the effect of seasonal variability on the marine environment in the corrosion of $\mathrm{Cu}$ and $\mathrm{Cu}$-Alloys was analyzed in situ with respect to exposure time. The possible changes in the mechanism of degradation, considering the physicochemical parameters of seawater were studied. An electrochemical study was carried out with three metallic materials industrially used (copper, bronze and brass) for 10 months of continuous exposure in seawater surrounding the San Juan de Ulua Fortress in Veracruz port, Mexico. Electrochemical impedance spectroscopy (EIS) was the electrochemical technique used. Additionally, a characterization of the metal surface with scanning electron microscopy (SEM) and X-ray diffraction (XRD) was carried out. All materials showed good corrosion resistances; however, copper showed higher resistance which took their best values in the last months of exposure presenting a layer of products of $\mathrm{Cu}_{2} \mathrm{O}$. Additionally, some silicates and sulfates were detected. Pitting and localized corrosion type was observed.

Keywords: Seasonal variability, copper, copper alloys, corrosion, EIS, seawater.

\section{FULL TEXT}

(C) 2017 The Authors. Published by ESG (www.electrochemsci.org). This article is an open access article distributed under the terms and conditions of the Creative Commons Attribution license (http://creativecommons.org/licenses/by/4.0/). 